\title{
Correlation between UPI Sports Science Program Students' Knowledge and Their Supplement Consumption Behavior
}

\author{
Imas Damayanti*, Yati Ruhayati, Nur Indri Rahayu \\ Departemen Pendidikan Kesehatan dan Rekreasi \\ Universitas Pendidikan Indonesia \\ Bandung, Indonesia \\ *imas_d@upi.edu
}

\begin{abstract}
This research was aimed at knowing sport science program students' knowledge and behavior toward food and drug supplement consumption used for sport performance. Method used was descriptive correlation using questionnaire and interview technique. Results showed that students' knowledge level was varied from poor until average $(25 \%$ poor, $75 \%$ average). While the students' behavior were considered between bad and fair $(42,5 \%$ bad and $57,5 \%$ fair. There was a significant correlation between students' level of knowledge and their behavior.
\end{abstract}

Keywords—knowledge level; consumption behavior; supplement; students

\section{INTRODUCTION}

Recently, drug and food supplements are used widely in our society, moreover by sport practitioners [1]. Drugs and food supplements indeed provide a lot of advantages. However, besides the supplements' idolization, there are some negative side effects that must be taken into consideration before used. The side effects include minor disease until death $[2,3,4]$. Unfortunately not all supplement consumers realize these risks. Sport science program students (IKOR UPI) are students actively doing sports because of their courses and also because there are a lot of them are professional athletes in many sports. For that reason, those students are one of groups have tendency to use drugs and food supplements for sport performance goals. Those students are also future sport science experts who will be in society providing knowledge they get in college for people, specially sports people.

\section{METHOD}

Research was conducted for 5 months (Mei-August 2011). It took place at FPOK UPI Bandung. It was correlation descriptive study. The subjects were sport science program students. The instruments used were a test for students knowledge regarding drugs and food supplements and a questionnaire about students' behavior in consuming drugs and food supplements for sport performance targets. Participants were 40 freshmen, who has not receive sport drugs class.

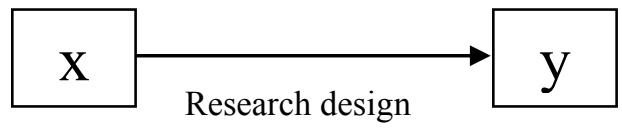

Abbreviations:

$\mathrm{X}=$ students; knowledge

$\mathrm{Y}=$ supplement consumption behavior

$\mathrm{R}=$ correlation between knowledge and behavior

Data was analyzes using Pearson Correlation test with significance $95 \%$.

Fig. 1. The design was ex post facto research

\section{RESULTS}

\section{A. Descriptive Analyzes}

1) UPI sport science program students' knowledge regarding $C$

TABLE I. STUDENTS' KNOWLEDGE

\begin{tabular}{|l|l|l|l|}
\hline \multicolumn{1}{|c|}{ Mean } & \multicolumn{1}{c|}{ Frequency } & \multicolumn{1}{c|}{ Percentage (\%) } & Level \\
\hline $1.00-2.49$ & 10 & $25 \%$ & Poor \\
\hline $2.50-3.50$ & 30 & $75 \%$ & Fair \\
\hline Total & 40 & 100.0 & \\
\hline
\end{tabular}

According to the table above, students' knowledge level regarding drugs and food supplement used for sport performance goals are $25 \%$ poor and $75 \%$ fair.

2) UPI sport science program students' UPI sport science program students' supplement consumption behavior

TABLE II. SUPPLEMENT CONSUMPTION BEHAVIOR

\begin{tabular}{|l|l|l|l|}
\hline \multicolumn{1}{|c|}{ Mean } & \multicolumn{1}{|c|}{ Frequency } & \multicolumn{1}{c|}{$\begin{array}{c}\text { Percentage } \\
(\mathbf{\%})\end{array}$} & Level \\
\hline $1.00-2.49$ & 17 & $42.5 \%$ & poor \\
\hline $2.50-3.50$ & 23 & $57.5 \%$ & fair \\
\hline Total & 40 & 100.0 & \\
\hline
\end{tabular}


According to the table above, students' behavior level regarding drugs and food supplement consumption are $42,5 \%$ poor and $57,5 \%$ fair.

\section{B. Inferensional Analysis}

Correlation between UPI Sports Science Program Students' Knowledge and Their Supplement Consumption Behavior.

TABLE III. Correlation Between UPI Sports SCIENCE Program STUDENTS' KNOWLEDGE AND THEIR SUPPLEMENT CONSUMPTION BEHAVIOR

\begin{tabular}{|c|c|c|l|}
\hline Correlation & r & Sig & \\
\hline Knowledge*behavior & $.547^{* *}$ & .000 & $\begin{array}{l}\text { Positive } \\
\text { correlation }\end{array}$ \\
\hline
\end{tabular}

According to the table above the correlation score is .547 with significance .000 , so $\mathrm{H} 0$ was denied, means there was significant correlation between UPI Sports Science Program students' knowledge and their supplement consumption behavior. According to the analyzes better knowledge will lead to better behavior.

\section{DISCUSSION}

Sport science program students (IKOR UPI) are students actively doing sports because of their courses and also because there are a lot of them are professional athletes in many sports. For that reason, those students are one of groups have tendency to use drugs and food supplements for sport performance goals. Those students are also future sport science experts who will be in society providing knowledge they get in college for people, specially sports people. From data analyzed it was found that $25 \%$ students having poor knowledge while other $75 \%$ having fair level of knowledge regarding drugs and food supplements. No one having high level of knowledge. This fact was not a good news, and one must find out the background of students lack of knowledge, because supplements for sports are include in many of their courses during program [5].

From result there was also found that students' behavior regarding the supplements consumption were poor on $42.5 \%$ students and fair enough for other $57.5 \%$ students. Even though the proportion of students having fair behavior is higher than poor one, but $42.5 \%$ students having poor behavior must not being ignored. Those student were expected to have good judgment regarding their behavior.

There was significant correlation between UPI Sports Science Program students' knowledge and their supplement consumption behavior. Better knowledge will lead to better behavior

\section{REFERENCES}

[1] O. Molinero, S. Márquez, Use of nutritional supplements in sports: risks, knowledge, and behavioural-related factors. Nutrición Hospitalaria. 2009;24(2):128-34

[2] A. Passariello, P. Agricole, P. Malfertheiner, A critical appraisal of probiotics (as drugs or food supplements) in gastrointestinal diseases. Current medical research and opinion. 2014 Jun 1;30(6):1055-64.

[3] Direktorat Bina Farmasi Komunitas dan Klinik. 2006. Pedoman Penggunaan Obat Bebas dan Bebas Terbatas. Ditjen Bina Kefarmasian dan Alat Kesehatan Departemen Kesehatan: Jakarta

[4] W.D. McArdle, Essentials of Exercise Physiology. Pennysylvania: Lea\&Febiger, 1994.

[5] I. Wolinsky, Nutrition In Exercise and Sport. Philadelphia: CRC Press, 1994. 